\title{
Bulk Paddy Grain Ageing Period Classification using RGB and HSI Color Features
}

\author{
Basavaraj S. Anami \\ Department of Computer \\ Science and Engineering, K L \\ E Institute of Technology, \\ Hubli, 580030, India.
}

\author{
Naveen N. M. \\ Department of Information \\ Science and Engineering, $\mathrm{K} \mathrm{L}$ \\ $E$ Institute of Technology, \\ Hubli, 580030, India.
}

\author{
N. G. Hanamaratti \\ Department of Genetics and \\ Plant Breeding, University of \\ Agricultural Sciences, \\ Dharwar, 580002, India.
}

\begin{abstract}
Paddy (rough rice) grain age assessment is one of the requirements in the rice industry as it has significant effects on processing and quality of products. This paper presents a color based approach for the classification of fifteen leading paddy varieties and their ageing periods from their bulk grain sample images. Five different ageing periods are considered, namely, 1, 3, 6, 9 and 12 months. Since color changes are observed with ageing, the features from RGB and HSI color spaces are used in the classification. The performance based feature reduction technique is adopted for feature reduction. The average ageing period classification accuracies of $93.60 \%, 92.40 \%, 91.87 \%, 93.33 \%$ and $94.13 \%$ are obtained for ageing periods of $1,3,6,9$ and 12 months respectively across the varieties using BPNN. The work finds application in automated pricing and grading, decision on suitability for value added products in food industry, developing a machine vision system in agriculture produce market (APMC) etc.
\end{abstract}

\section{General Terms}

Image classification, Pattern Recognition

\section{Keywords}

Rice, Age assessment, Husk color, stored food grains, BPNN.

\section{INTRODUCTION}

Paddy is the most important domesticated cereal of Asia covering about one-fourth of the total cropped area and feeds half the world. The paddy crop is grown throughout the year, at best twice in a year. Whereas in tropical regions, paddy is frequently harvested in a year and due to the extreme environmental conditions, it usually stored for a short period. But being the staple food of humankind, it is required all the year round. Therefore, the paddy grains have to undergo long storage for up to a year or more like other cereal grains. Paddy grains immediately after harvest are normally a natural golden yellowish in color but in storage they usually discolor. During the storage, paddy grains undergo several physicochemical and physiological changes [16]. The physicochemical properties include in starch changes, fat oxidation, changes in cell walls and protein. The physiological properties include all the external characteristics, such as size, shape, color and smoothness. The knowledge of physiological properties of paddy is very much necessary in all the activities from harvesting, drying, storage, milling, packaging, marketing, cooking, product making and utilization.

Storage-induced ageing of paddy grains has both desirable and undesirable effects on the end product depending on the storage conditions and varieties. Rice (milled paddy) is a unique food crop among other food grains in that it undergoes significant change in its organoleptic cooking and eating behavior with the progress of time during storage. Soon after harvest, rice tends to cook generally sticky, lumpy and moist mass. This character gradually changes over time. After six months of storage, rice cooks comparatively more dry, soft and free flowing. Thus, aged rice is preferred in testing for milling and cooking properties. Bran oil, wine and vinegar are the other end products of aged paddy. This pattern of usage results in the need to store paddy over varying periods and peoples' preference varies for fresh or aged paddy based on the end products. Ageing profoundly affects consumer acceptance and processing behavior of paddy grains. Also it can improve the quality of paddy grains and widens the marketability. In fact, there is a substantial price differential between new and old paddy and people are happy to pay a higher price for old paddy. So a proper paddy grain age assessment technique is necessary for consumers and traders for domestic use as well as the traders for their commercial use.

One of the most sensitive indices of the ageing process in paddy grains is the change in husk color or discoloration of husk (paleo or seed coat) due to $\mathrm{pH}$, free fatty acids and enzyme activities. This forms the basis for the present work. The trained personnel visually observe the husk color to determine the grain age. This visual inspection is subjective and tedious by nature. An objective, rapid and automatic grain age assessment system would be beneficial to the potential farmers and consumers in getting the right aged paddy grains.

To know the state-of-the-art in automation of grain age assessment in the field of food grains, a survey is made and the gist of a survey is given as under.

Azman [2] proposed the potential of color indices to determine the moister content and maturity stage of paddy using color properties extracted from RGB and thermal images. Five color indices such as Red Index, Green Index, Blue Index, Thermal Red Index and Thermal Index are used to analyze the maturity stage and moister content. Red index gave the best model of paddy maturity and moisture content estimation compared to other color indices with $99.2 \%$ and 99.1\% percentage of successful estimation, respectively. Azman [4] presented a new technique of paddy maturity estimation using seven color indices extracted from RGB color space. The color indices are Red, Green, Blue, difference between Green and Blue, difference between Green and Red, Green to Blue Ratio, and Green to Red Ratio. The results showed that the color indices gave significant correlation with the maturity stage of paddy. Haw [5] proposed the color vision methodology to determine Malaysian paddy grain maturity from the hue color and weight of the florets.

Site [6] presented an image processing technique to identify mature and immature paddy grains using mean, median, standard deviation and Otsu features extracted from segmented images. Golpour [7] proposed an image processing algorithm for classification bulk paddy, brown and 
white rice of five rice cultivars using 36 color features in RGB, HIS and HSV color spaces. The backpropagation neural network was used for classification and obtained mean classification accuracy of $96.66 \%$ with 13 color features. Khongsak [9] applied chemiluminescence system to analyze the color of chemical solutions changed with regards to the age of rice grains. $L^{*} a^{*} b^{*}$ color space was employed to determine the color bands of fresh and aged rice grains. Liu [10] proposed an image processing method to detect the color of fresh and old rice using RGB and HSI color models and concluded that the fresh rice is brighter than the old rice. Maturada [13] proposed a rice quality evaluation method using HSI color space to evaluate various kernel defects, including kernel discolorations and chalkiness. Xiaoli [14] presented Chemometrics method coupled with on visible/near infrared (Vis/NIR) reflectance spectroscopy for discriminating paddy seeds stored for four different ageing periods namely one, two, three and four years. A total of 210 samples of paddy seeds, which belonged to four classes were used for collecting Vis/NIR spectra. The spectral data was processed and analyzed using wavelet transform. The feature reduction was performed using principal component analysis (PCA). ANN with backpropagation model was used for ageing period discrimination and obtained accuracy rates of $100 \%, 100 \%$, $100 \%, 90 \%$ for the selected four ageing periods respectively. The mean discrimination accuracy rate of $97.5 \%$ was achieved using eight principal component features. Nambi [3] proposed a scheme for the evaluation of color behavior during ripening of mango using RGB color measurements. The changes in RGB values in each day during ripening were recorded and it was found that the ripening days significantly influence the color change. The changes in red ratios $(\mathrm{R} / \mathrm{G}$, $\mathrm{R} / \mathrm{B})$, green ratios $(\mathrm{G} / \mathrm{R}, \mathrm{G} / \mathrm{B})$ and blue ratios $(\mathrm{B} / \mathrm{R}, \mathrm{B} / \mathrm{G})$ were calculated and used to predict the ripening. Belovic [8] proposed a color change evaluation technique for paprica powder during storage from its surface color using CIE $\mathrm{L} * \mathrm{a} * \mathrm{~b} *$ color space. The change of reflected color of paprika powder during three years of storage was characterized by increase of $\mathrm{L}^{*}$ (lightness) and $\mathrm{b}^{*}$ (yellowness) color values and decrease of $a^{*}$ (redness) color value. Effendi [11] developed a grading method to classify Jatropha Curcas fruit into raw, ripe and overripe by analyzing surface color. Backpropagation neural network was used in the classification process and obtained an accuracy of about 95\%. Ali [12] proposed classification of hard wheat, tender wheat and barley using morphological, color and wavelet features with the help of ANN classification method with the best recognition rate of 98\%. Visen [15]; Majumdar and Jayas [17], Majumdar and Jayas [18] proposed a method for identifying bulk cereal grains using color features.

From the literature survey, it is observed that Xiaoli [1] has presented Chemometrics method coupled with on visible/near infrared (Vis/NIR) reflectance spectroscopy for discriminating paddy seeds stored for four different ageing periods namely one, two, three and four years. Only four varieties are considered and limited number of samples are used in the work. It is also observed in consultation with experts that, a rapid change in paddy husk color occurs during the first year of natural storage and the husk color change is more gradual after one year. This is the motivation for the present work.

Some works are also being carried out for classification of husked paddy (rice kernel) grains into fresh and old based on color indices, while certain studies have been made on using image analysis to discriminate paddy varieties based on shape and color features. Few works have been reported on using image analysis to evaluate various rice kernel defects and chalkiness. To the authors' knowledge, there is scope for classification of ageing periods from bulk paddy grain images, considering more varieties and more samples.

The remaining part of the paper is organized into five sections. Section 2 gives the description of the proposed methodology. Section 3 gives the explanation of image dataset preparation. Section 4 presents the variety recognition methodology from bulk paddy grain sample images. Section 5 gives the description of the process of ageing period classification, summary of the results with concluding remarks and suggestions for future scope.

\section{PROPOSED METHODOLOGY}

The proposed methodology consists of two main phases. The first phase is for variety recognition, where paddy variety is identified. The second phase is for classification of ageing periods, where selected five ageing periods in months are predicted. The block diagram illustrating the steps involved in the proposed methodology is shown in Fig 1.

\section{IMAGE DATASET}

In consultation with the University of Agricultural Sciences (UAS), Dharwad, Karnataka State, India, fifteen certified and popular paddy varieties are selected as grain samples in the work. The matured and disease free paddy varieties are obtained from Agricultural Research Station, Mugad, Dharwad. These varieties are grown in different parts of Karnataka, India. The paddy grain samples are cleaned with an air-screen cleaner to remove all foreign matter such as dust, dirt, stones, chaff, immature and broken seeds and packed in polyethylene bags before analysis. The names of the paddy varieties considered in the work are Abhilasha, Bhagyajyothi, Budda, Intan, Jaya, Jayashree, Mugad Dodiga, Mugad Sughand, Mugad 101, Mugad Siri, PSB 68, Rajkaima, Redjyothi, Thousand One and Thousand Ten.

Images of bulk paddy grain samples from fifteen paddy varieties at five different ageing periods are acquired. The image data set used for the experimentation comprises 7500 images, considering 500 images (100 images per ageing period) from each of the paddy varieties. Freshly harvested paddy grains of one month old are considered in the first ageing period. In the second, third, fourth and fifth ageing periods, paddy grains aged at three, six, nine and twelve months old are considered respectively.

The images are captured under standard lighting conditions using color camera PENTAX MX-1, USA, having resolution of 14 mega pixels. The camera has a zoom lens of 10-120 mm focal length and a $72 \mathrm{~mm}$ close-up lens set. The camera is vertically oriented and approximately a distance of 0.5 meters is maintained while capturing the images. The acquired images of size 1920 X 1080 pixels are cropped to size $400 \mathrm{X}$ 400 pixels for the reasons of reduction in computational overhead and storage requirements in order to achieve easier training. The images of selected paddy varieties at five different age intervals are shown in Table 1.

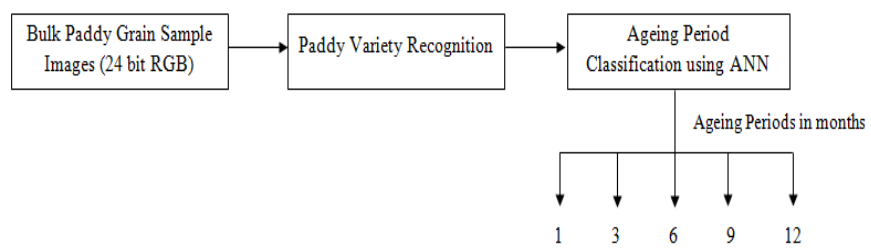

Fig 1. Block diagram of the proposed methodology 


\section{VARIETY RECOGNITION}

In this phase, an edge texture features based methodology is employed to recognize the paddy varieties [1]. Because variation in shape or texture properties of bulk paddy grains due to ageing is negligible for the considered fifteen paddy varieties and five ageing periods. The edge images required for the variety recognition process are obtained using maximum gradient edge detection method. The average paddy variety recognition accuracy of $87.80 \%$ was obtained for the reduced eight texture features. The output of this phase is given to the second phase as one of the inputs for the classification of ageing periods. However, the authors are currently working on improving the variety recognition accuracy.

\section{AGEING PERIOD CLASSIFICATION}

Paddy husk (seed cover) color is an important visual attribute used in ageing period classification and its color varies from variety to variety. The ageing induces discoloration of husk. So, the color based methodology has been employed for the classification of the ageing periods. This phase is composed of following four stages, namely feature extraction, feature reduction, classification of ageing periods and discussion of results.

\subsection{Color feature extraction}

Varietal differences and grain ageing for several paddy varieties can be easily classified using color information. The paddy grain husk color is an influential feature and strongly correlates with ageing. So it is used as a descriptor in classification of ageing periods from bulk paddy grain sample images. The bulk paddy grain images captured at different periods of ageing offer a tremendous amount of spatial resolution and color differences, which can be used to quantify the color distribution. To study the extent of color differences, the RGB and HSI color spaces are used and the characterization of the images is done through a series of RGB histograms. The histograms of the RGB pixel data distribution in bulk paddy grain sample images captured at five ageing periods clearly show the presence of different density distribution of RGB color primaries. It clearly states that the Red, Green and Blue color components can be quantified and the feature values can be easily used for discriminating analysis. To extract the color features independent of external illumination RGB color space is converted to HSI color space. The color features of HSI color space are combined with RGB color space features to analyze the color intensity and match actual human eye color sensitivity in ageing period classification.

The following method is adopted in extracting color features from the RGB images of bulk paddy grain. The primary step is the separation of Red (R), Green (G) and Blue (B) channels from the original color images. The next step is to extract Hue $(\mathrm{H})$, Saturation (S) and Intensity (I) components from the RGB channels using the equations (1) through (3). In the further step the global color features such as mean, standard deviation, median and range are computed from all the individual $\mathrm{R}, \mathrm{G}, \mathrm{B}, \mathrm{H}, \mathrm{S}$, and I color components using equations (4) through (10). A total of twenty four color features is extracted from the bulk paddy grain sample images and the features are listed in Table 2. The graphical representation of color feature values for a paddy variety Abhilasha is shown in Fig 2.

$$
\begin{aligned}
& H=\cos ^{-1}\left\{\frac{\frac{1}{2}[(R-G)+(R-B)]}{\left[(R-G)^{2}+(R-B)(G-B)\right]^{\frac{1}{2}}}\right\} \\
& S=1-\frac{3}{(R+G+B)}[\min (R, G, B)] \\
& I=\frac{1}{3}(R+G+B) \\
& \operatorname{Mean}(\mu)=\frac{1}{N} \sum_{i=1}^{N} X_{i}
\end{aligned}
$$

Where $\mathrm{N}$ is the total number of pixels, $x_{i}$ is the $\mathrm{i}^{\text {th }}$ pixel value.

Standard Deviation $(\sigma)=\frac{1}{\mathrm{~N}} \sum_{\mathrm{i}=1}^{\mathrm{N}} \sqrt{\left(\mathrm{x}_{\mathrm{i}}-\mu\right)^{2}} \quad \ldots$

Median is the middle value of the histogram. If $\mathrm{N}$ is odd,

Median $(\mathrm{m})=$ Pixel value of $\left(\frac{\mathrm{N}+1}{2}\right)^{\text {th }}$ pixel $\quad \ldots$

If $\mathrm{N}$ is even,

Median $(\mathrm{m})=$ Pixel value of $\frac{1}{2}\left\{\left(\frac{\mathrm{N}}{2}\right)^{\text {th }}\right.$ pixel $+\left(\frac{\mathrm{N}+1}{2}\right)^{\text {th }}$ pixel $\}$

Maximum element and minimum elements of the given input color (RGB) image is calculated using Equation (8).

$\max 1=\max ($ image $), \max 2=\max (\max 1)$

The above function returns the row vector containing the maximum element from each column. Similarly, find the minimum element from the whole matrix using Equation (9).

$\min 1=\min ($ image $), \min 2=\min (\min 1)$

Range is the difference between the maximum and minimum elements and is given in the Equation (10).

Range $=\max 2-\min 2$

\subsection{Performance based color feature reduction}

In the present case, there are twenty four color features extracted from the images of bulk paddy grain. Some of them may be redundant and highly correlated. So, it is therefore, necessary to eliminating such color features thereby constructing effective reduced feature set which leads to satisfactory classification results. In order to improve the ageing period classification accuracy results, a performance based feature reduction process is performed. In this process the average ageing period estimation performance of individual color feature for all the paddy varieties is evaluated and then threshold based feature reduction operation is performed by considering the average ageing period classification accuracies of all the color features. The reduced feature sets are constructed from the color features whose individual average classification accuracies are equal or greater than the decided performance threshold value. The classification accuracies of all the individual color features are given in Table 4. From Table 4, the highest and lowest average ageing period classification accuracies of $54.70 \%$ and $15.46 \%$ are obtained for individual color features Red Mean and Blue Range respectively. 


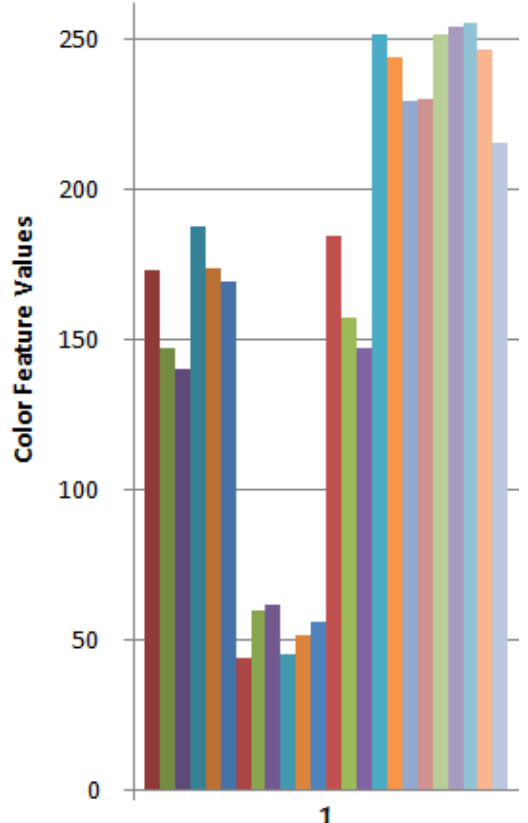

Period of Ageing in months

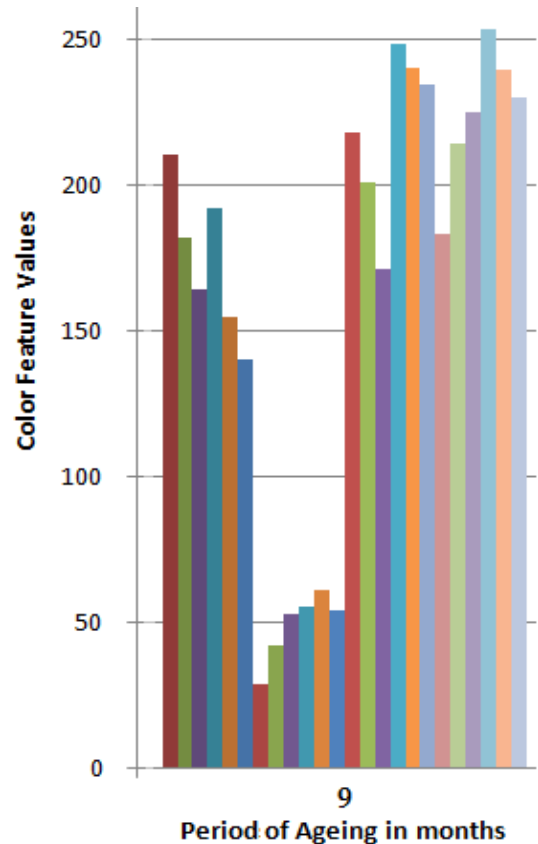

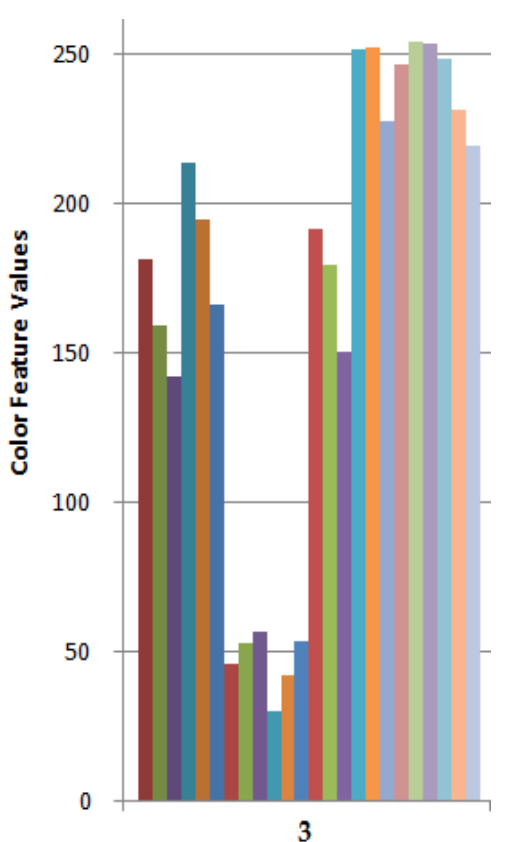

Period of Ageing in months

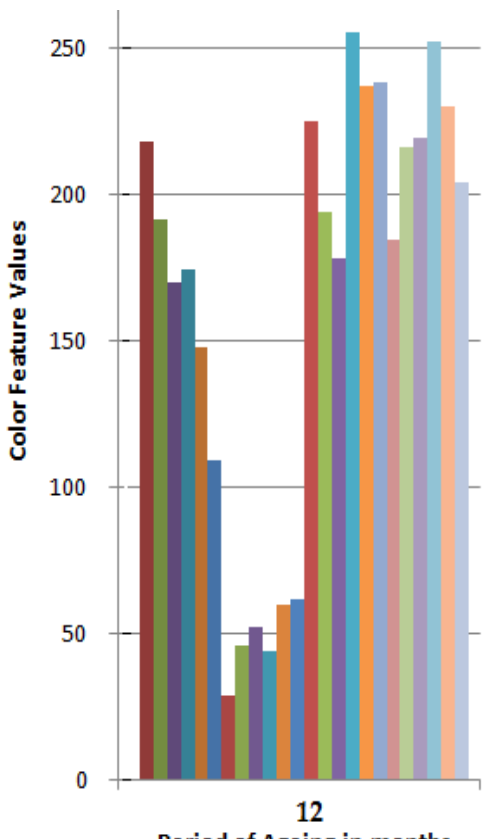

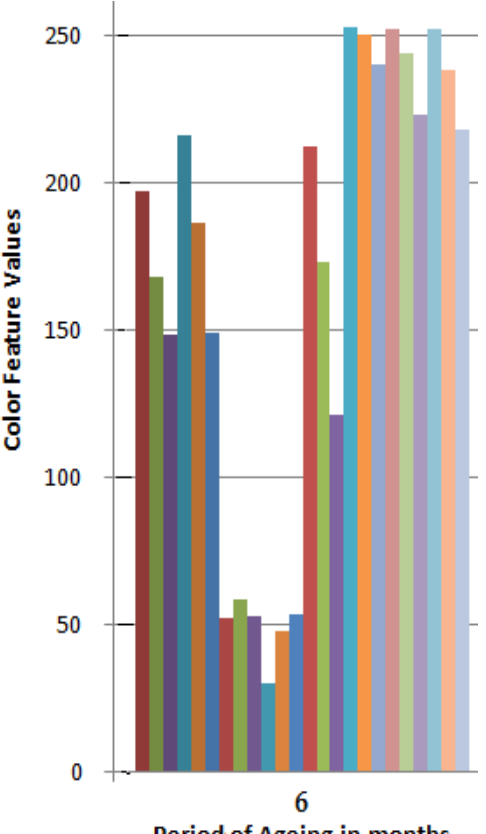

Period of Ageing in months

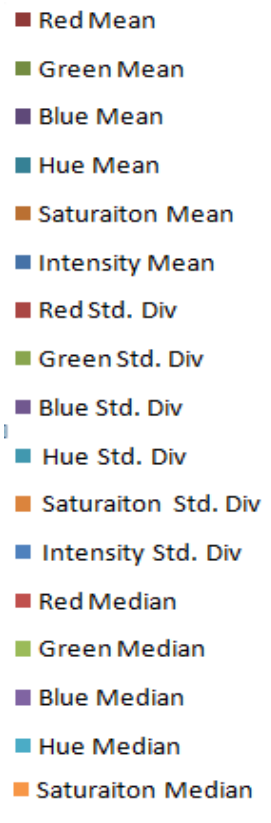

n Intensity Median

Fig 2. Graphical representation of color feature values of the paddy variety Abhilasha at five different ageing periods.

The initial performance threshold value is empirically determined as $25 \%$ and it is incremented by $5 \%$ every time to construct new reduced feature sets. Based on the classification results from Table 4, three different reduced color feature sets are constructed by setting three different performance threshold values and the summary of all reduced feature sets is given in Table 5. These reduced feature sets are then used for training and testing BPNN to perform classification of ageing periods from bulk paddy sample images.

A separate training and testing are carried out for the reduced feature sets R1, R2 and R3. The summarized ageing period classification results using reduced feature sets are given in Table 6. From Table 6, the results show that the reduced feature set R2 outperforms the other reduced feature sets R1,
R3 and the full feature set with all the color features. The maximum and minimum average ageing period classification accuracies of $93.07 \%$ and $81.49 \%$ are obtained for the reduced feature sets R2 and R3 respectively.

The color features in reduced color feature set R2 are given in Table 7. The detailed classification summary of ageing periods for all the paddy varieties using reduced color features from R2 is given in Table 8. From Table 8, the maximum and minimum average ageing period classification accuracies of $94.40 \%$ and $91.87 \%$ are obtained for ageing periods 12 and 6 months respectively. The average classification accuracy of $93.07 \%$ is achieved from all the ageing periods. 


\subsection{Classifier}

Multilayer Backpropagation Neural Network (BPNN) has been used as a classifier for the present work. The number of neurons in the input layer is set to the number of appropriate color features selected as input and the output layer is set to the number of ageing periods of all the fifteen paddy varieties considered i.e. 75 ( 5 ageing periods for each of the fifteen paddy varieties). Levenberg-Marquardt (LM) backpropagation algorithm is used for the training. The termination error (TE) is set to 0.01 , learning rate $(\eta)$ is set to 0.05 and momentum coefficient $(\mu)$ is set to 0.6. The sigmoid activation functions are used in the hidden layers. The network is trained and tested for 1000 epochs. With these parameters, the classifier is trained and tested using images of bulk paddy grain from fifteen paddy varieties captured at five different ageing periods. The sample images are divided into two halves and one half is used for training and other is used for testing. The color features are used to train and test neural network model. The percentage accuracy of ageing period classification is defined as the ratio of correctly classified sample images to the total number of sample images considered.

\subsection{Results and discussion}

In the proposed methodology, a total of 7500 images from fifteen paddy varieties captured at five different periods of ageing (100 images per ageing period per paddy variety) are considered. Out of these, 3750 images are used for training the BPNN and remaining 3750 images are used for testing.

Classification experiments have been carried out for ageing period classification using color features extracted from the images of bulk paddy grain samples. Initially, twenty four color features extracted from RGB and HSI color spaces are used to train and test the BPNN and obtained average ageing period classification accuracy of $71.55 \%$. To improve the accuracy result, a performance based feature reduction method is employed. Ten reduced color features from RGB and HSI color spaces yield very good average ageing period classification accuracy of $93.07 \%$.

The overall ageing period classification accuracy of the proposed method is analyzed by drawing the confusion matrix. The confusion matrix of the present work is given in Table 9 (Assuming paddy variety recognition accuracy is $100 \%$ ). From the confusion matrix, among all the 3750 images, the ageing periods from 3493 images are correctly classified, thus resulted in an overall accuracy of $93.15 \%$.

A total of 750 images from all fifteen paddy varieties captured at five different periods of ageing are subjected for expert classification and obtained ageing period classification accuracy of $98.5 \%$. The classification results of the proposed work are compared with the similar work reported [1] and the improvements are listed in Table 10. However, the authors could not make an exact comparison due to many differences in the two approaches. The experimental results have shown that the color features from RGB and HSI color spaces are suitable for classification of ageing periods from bulk paddy grain sample images.

\subsection{Conclusion}

In the proposed methodology, the classification of ageing periods of bulk paddy grain samples from fifteen paddy varieties using image processing techniques is effectively executed. The color features from Red, Green, Blue, Hue and Intensity color planes are significantly related to the ageing of bulk paddy grains. The experimental results show that ageing periods for bulk paddy grain are fairly estimated using reduced RGB and HSI color features. The proposed methodology has yielded promising results with the average ageing period classification accuracy of $93.07 \%$ for all the fifteen bulk paddy grain sample images acquired at five different periods of ageing.

The work finds application in automated pricing and grading, decision on suitability for value added products in the food industry, developing a machine vision system in the agricultural produce markets (APMC) etc. The generality of the proposed methodology can make it applicable in a wide range of computer vision tasks in the field of grain handling and food industry. The work is complex and challenging in terms of high irregularity in an outdoor environment. Effects of storage conditions on the classification of ageing periods can be the factor for further studies.

\section{REFERENCES}

[1] Anami, Basavaraj S., Naveen Nagendrappa Malvade, and N. G. Hanamaratti. 2016. An edge texture features based methodology for bulk paddy variety recognition, Agricultural Engineering International: CIGR Journal $18.1: 399-410$

[2] Norsolehah Azman, Siti Khairunniza-Bejo, Wan Ishak Wan Ismail and AimrunWayayok. 2015. Development of Fresh Harvested Paddy Quality Determination Model Using Color Indices, Australian Journal of Basic and Applied Sciences, 9(28), Pages: 50-56.

[3] Nambi, V.E., Thangavel, K., Shahir, S. and Geetha, V. 2015. Evaluation of color behavior during ripening of Banganapalli mango using CIE-Lab and RGB color coordinates, Journal of Applied Horticulture, 17(3), pp.205-209.

[4] Norsolehah Azman, Siti Khairunniza-Bejo, Wan Ishak Wan Ismail, and Aimrun Wayayok. 2014. Estimating Maturity of Paddy Using RGB Color Space, Journal of Advanced Agricultural Technologies Vol. 1, No. 2.

[5] Choe Lip Haw , Wan Ishak Wan Ismail , Siti KairunnizaBejo , Adam Putih and Ramin Shamshiri. 2014. Color vision to determine paddy maturity, International Journal of Agricultural and Biological Engineering, 7(5), 55-63.

[6] S. Khairunniza-Bejo and N. Sudin. 2014. Mature and immature paddy identification using image processing technique. Journal of Engineering Science and Technology, Vol. 9, No. 3, pp. 326 - 333.

[7] Golpour, I., Parian, J.A. and Chayjan, R.A. 2014. Identification and classification of bulk paddy, brown and white rice cultivars with color features extraction using image analysis and neural network, Czech Journal Food Science, Vol. 32, No. 3, pp.280-287.

[8] Belovic, Miona M., Jasna S. Mastilovic, and Zarko S. Kevresan. 2014. Change of surface colour parameters during storage of paprika (Capsicum annuum L.), Food and Feed Research 41, No. 2, pp.85-92.

[9] Khongsak SRIKAEO, \& Uttaphon PANYA. 2013, Efficiencies of chemical techniques for rice grain freshness analysis, Rice Science, 20(4), 292-297.

[10] Liu Guang-rong. 2010. Rice color inspection based on Image Processing Technique, in International Conference on Advances in Energy Engineering (IEEE), ISBN No. 978-1-4244-7830-9, pp. 134-137. 
[11] Effendi, Z., Rizauddin Ramli, and Jaharah A. Ghani. 2010. A Backpropagation Neural Networks for Grading Jatropha curcas Fruits Maturitiy, American Journal of Applied Sciences 7, no. $3: 390$.

[12] Douik Ali, and Mehrez Abdellaoui. 2010. Cereal grain classification by optimal features and intelligent classifiers, International Journal of Computers Communications \& Control 5.4: 506-516.

[13] Maturada Jinorose, Prachayawarakorn Somkiat, and Soponronnarit Somchart. 2010. Development of a computer vision system and novel evaluation criteria to characterize color and appearance of rice, Drying Technology 28, no. 9: 1118-1124.

[14] Xiaoli Li, Yong He, and Changqing Wu. 2008. Nondestructive discrimination of paddy seeds of different storage age based on Vis/NIR spectroscopy, Journal of Stored Products Research, 44(3), pp. 264-268.
[15] Visen, N.S., J. Paliwal, D.S. Jayas and N. D. G. White. 2004. Image analysis of bulk grain samples using neural networks, Canadian Biosystems Engineering 46:7.117.15 .

[16] Zhou, Z., K. Robards, S. Helliwell, and C. Blanchard. 2002. Ageing of stored rice: changes in chemical and physical attributes, Journal of Cereal Science 35, no. 1, 65-78.

[17] Majumdar, S. and D.S. Jayas. 2000b. Classification of cereal grains using machine vision: II. Color models, Transactions of the ASAE 43(6):1677-1680.

[18] Majumdar, S., \& Jayas, D. S. 1999. Classification of bulk samples of cereal grains using machine vision, Journal of Agricultural Engineering Research, 73(1), 35-47.

\section{APPENDIX}

Table 1. Bulk paddy grain images in five different ageing periods.

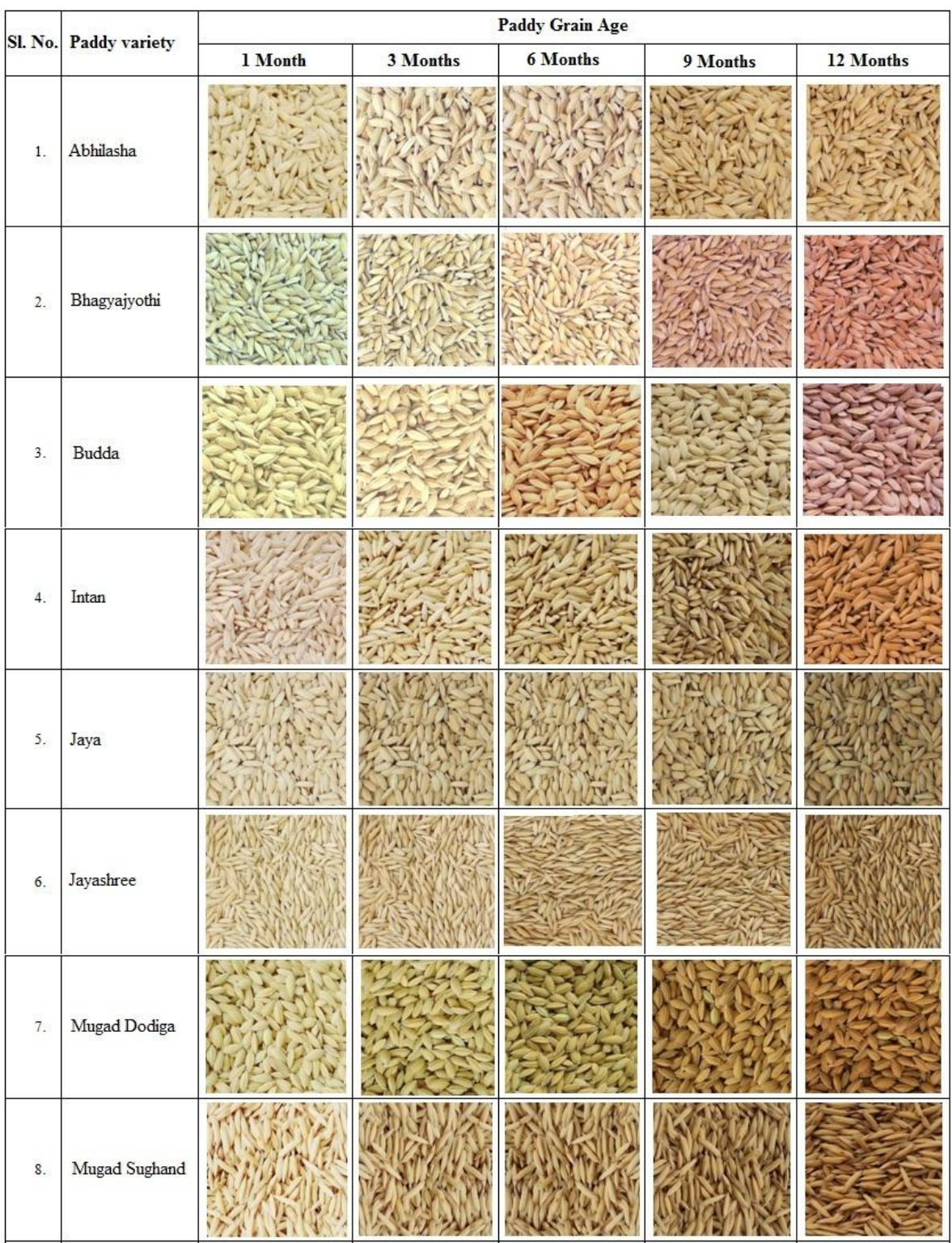


Table 1. Bulk paddy grain images in five different ageing periods (Continued...).

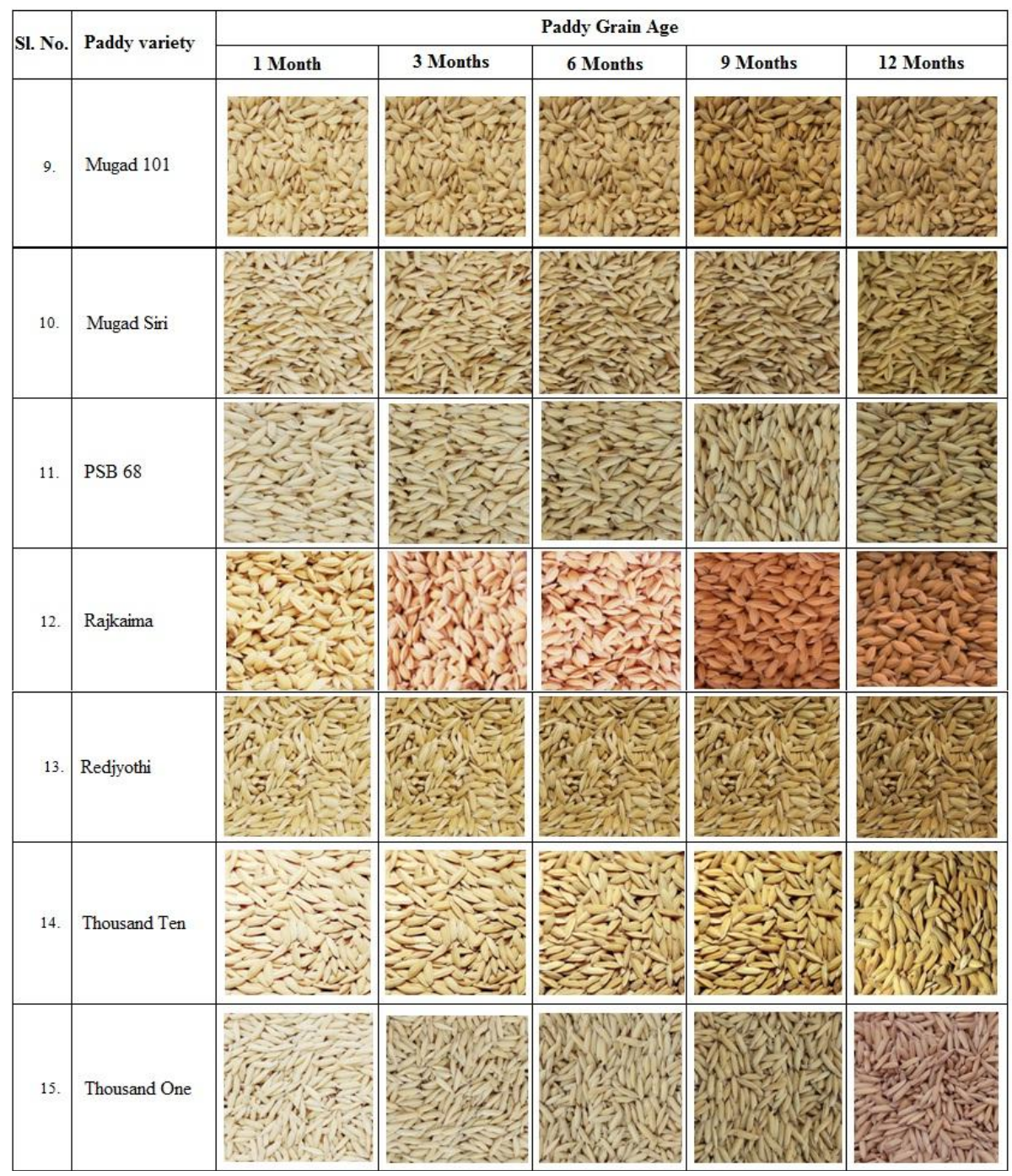

Table 2: RGB and HSI color features.

\begin{tabular}{|c|l|c|l|c|l|}
\hline $\begin{array}{c}\text { Sl. } \\
\text { No. }\end{array}$ & \multicolumn{1}{|c|}{ Color feature } & $\begin{array}{c}\text { Sl. } \\
\text { No. }\end{array}$ & \multicolumn{1}{|c|}{ Color feature } & $\begin{array}{c}\text { Sl. } \\
\text { No. }\end{array}$ & \multicolumn{1}{|c|}{ Color feature } \\
\hline 1 & Red Mean & 9 & Blue Mean & 17 & Saturation Mean \\
\hline 2 & Red Standard Deviation & 10 & Blue Standard Deviation & 18 & Saturation Standard Deviation \\
\hline 3 & Red Median & 11 & Blue Median & 19 & Saturation Median \\
\hline 4 & Red Range & 12 & Blue Range & 20 & Saturation Range \\
\hline 5 & Green Mean & 13 & Hue Mean & 21 & Intensity Mean \\
\hline 6 & Green Standard Deviation & 14 & Hue Standard Deviation & 22 & Intensity Standard Deviation \\
\hline 7 & Green Median & 15 & Hue Median & 23 & Intensity Median \\
\hline 8 & Green Range & 16 & Hue Range & 24 & Intensity Range \\
\hline
\end{tabular}

Table 3. Ageing period classification results using twenty four color features.

\begin{tabular}{|c|l|c|c|c|c|c|}
\hline \multirow{2}{*}{ Sl. No } & \multirow{2}{*}{ Paddy variety } & \multicolumn{5}{|c|}{ Classification accuracy per ageing period (\%) } \\
\cline { 3 - 7 } & & $\mathbf{1}$ Month & 3 Months & 6 Months & 9 Months & 12 Months \\
\hline 1 & Abhilasha & 72 & 66 & 74 & 68 & 66 \\
\hline 2 & Bhagyajyothi & 68 & 70 & 78 & 64 & 68 \\
\hline 3 & Budda & 70 & 68 & 70 & 66 & 68 \\
\hline 4 & Intan & 72 & 72 & 66 & 68 & 70 \\
\hline 5 & Jaya & 74 & 72 & 78 & 72 & 72 \\
\hline
\end{tabular}




\begin{tabular}{|l|l|c|c|c|c|c|}
\hline 6 & Jayashree & 60 & 76 & 76 & 74 & 76 \\
\hline 7 & Mugad Dodiga & 68 & 68 & 72 & 66 & 74 \\
\hline 8 & Mugad Sughand & 70 & 76 & 70 & 82 & 70 \\
\hline 9 & Mugad 101 & 72 & 66 & 68 & 80 & 72 \\
\hline 10 & Mugad Siri & 70 & 76 & 68 & 72 & 66 \\
\hline 11 & PSB 68 & 74 & 72 & 74 & 70 & 68 \\
\hline 12 & Rajkaima & 72 & 72 & 80 & 68 & 60 \\
\hline 13 & Redjyothi & 76 & 78 & 78 & 76 & 78 \\
\hline 14 & Thousand Ten & 78 & 68 & 78 & 74 & 72 \\
\hline 15 & Thousand One & 66 & 72 & 74 & 70 & 78 \\
\hline \multicolumn{2}{|l}{ Average ageing period } & 70.80 & 71.47 & 73.60 & 71.33 & 70.53 \\
\hline
\end{tabular}

Table 4: Performance of individual color feature in ageing period classification.

\begin{tabular}{|c|c|c|c|c|c|c|c|}
\hline \multirow{2}{*}{$\begin{array}{l}\text { Sl. } \\
\text { No }\end{array}$} & \multirow{2}{*}{$\begin{array}{l}\text { Color feature with feature } \\
\text { identifier }\end{array}$} & \multicolumn{5}{|c|}{ Classification accuracy per ageing period (\%) } & \multirow{2}{*}{$\begin{array}{c}\text { Average } \\
\text { classification } \\
\text { accuracy }(\%)\end{array}$} \\
\hline & & $\begin{array}{c}1 \\
\text { Month }\end{array}$ & $\begin{array}{c}3 \\
\text { Months }\end{array}$ & $\begin{array}{c}6 \\
\text { Months }\end{array}$ & $\begin{array}{c}9 \\
\text { Months }\end{array}$ & $\begin{array}{c}12 \\
\text { Months }\end{array}$ & \\
\hline 1 & Red Mean (F1) & 56.70 & 55.80 & 52.40 & 49.88 & 58.70 & 54.70 \\
\hline 2 & Red Standard Deviation (F2) & 46.60 & 49.20 & 56.30 & 51.20 & 40.20 & 48.70 \\
\hline 3 & Red Median (F3) & 23.32 & 22.34 & 32.11 & 29.50 & 31.23 & 27.70 \\
\hline 4 & Red Range (F4) & 20.54 & 23.26 & 24.23 & 22.35 & 28.25 & 23.73 \\
\hline 5 & Green Mean (F5) & 38.30 & 49.40 & 48.50 & 47.70 & 49.90 & 46.76 \\
\hline 6 & Green Standard Deviation (F6) & 34.50 & 38.40 & 42.10 & 34.20 & 46.30 & 39.10 \\
\hline 7 & Green Median (F7) & 14.50 & 16.40 & 17.40 & 10.20 & 21.30 & 15.96 \\
\hline 8 & Green Range (F8) & 13.20 & 14.20 & 15.20 & 17.90 & 19.50 & 16.00 \\
\hline 9 & Blue Mean (F9) & 43.40 & 41.50 & 51.80 & 42.50 & 40.20 & 43.88 \\
\hline 10 & Blue Standard Deviation (F10) & 41.10 & 30.60 & 40.50 & 43.50 & 36.90 & 38.52 \\
\hline 11 & Blue Median (F11) & 18.60 & 15.60 & 11.50 & 20.40 & 27.60 & 18.74 \\
\hline 12 & Blue Range (F12) & 17.20 & 23.30 & 10.60 & 7.50 & 18.70 & 15.46 \\
\hline 13 & Hue Mean (F13) & 49.00 & 43.60 & 43.60 & 42.84 & 36.03 & 43.01 \\
\hline 14 & Hue Standard Deviation (F14) & 37.71 & 36.56 & 38.85 & 35.90 & 38.68 & 37.54 \\
\hline 15 & Hue Median (F15) & 25.40 & 20.30 & 23.30 & 21.34 & 25.32 & 23.13 \\
\hline 16 & Hue Range (F16) & 17.80 & 20.20 & 22.43 & 23.30 & 26.40 & 22.03 \\
\hline 17 & Saturation Mean (F17) & 12.30 & 16.60 & 21.33 & 19.80 & 21.45 & 18.30 \\
\hline 18 & $\begin{array}{l}\text { Saturation Standard Deviation } \\
\text { (F18) }\end{array}$ & 29.17 & 29.47 & 30.43 & 28.56 & 31.48 & 29.82 \\
\hline 19 & Saturation Median (F19) & 19.76 & 22.09 & 24.73 & 23.89 & 26.44 & 23.38 \\
\hline 20 & Saturation Range (F20) & 19.40 & 29.80 & 31.67 & 29.82 & 32.46 & 28.63 \\
\hline 21 & Intensity Mean (F21) & 33.30 & 32.58 & 34.99 & 32.53 & 35.34 & 33.75 \\
\hline 22 & Intensity Standard Deviation(F22) & 32.78 & 36.45 & 32.30 & 28.70 & 31.20 & 32.29 \\
\hline 23 & Intensity Median (F23) & 24.18 & 27.12 & 28.89 & 27.09 & 29.86 & 27.43 \\
\hline 24 & Intensity Range (F24) & 22.68 & 26.07 & 27.79 & 26.12 & 28.88 & 26.31 \\
\hline
\end{tabular}


Table 5. Reduced color feature sets obtained by performance based feature reduction method.

\begin{tabular}{|c|c|l|c|c|}
\hline $\begin{array}{c}\text { SI. } \\
\text { No }\end{array}$ & $\begin{array}{c}\text { Performance } \\
\text { threshold (\%) }\end{array}$ & \multicolumn{1}{|c|}{ Reduced feature set } & $\begin{array}{c}\text { Reduced } \\
\text { feature set } \\
\text { size }\end{array}$ & $\begin{array}{c}\text { Reduced } \\
\text { feature set } \\
\text { identifier }\end{array}$ \\
\hline 1 & 25 & $\begin{array}{l}\text { F1, F2, F3, F5, F6, F9, F10, F13, F14, F18, F20, } \\
\text { F21, F22, F23, F24 }\end{array}$ & 15 & R1 \\
\hline 2 & 30 & F1, F2, F5, F6, F9, F10, F13, F14, F21, F22 & 10 & R2 \\
\hline 3 & 35 & F1, F2, F5, F6, F9, F10, F13, F14 & 8 & R3 \\
\hline
\end{tabular}

Table 6. Ageing period classification results of three reduced color feature sets.

\begin{tabular}{|c|c|c|c|c|}
\hline $\begin{array}{l}\text { Sl. } \\
\text { No }\end{array}$ & $\begin{array}{l}\text { Reduced feature } \\
\text { set identifier }\end{array}$ & $\begin{array}{l}\text { Ageing period } \\
\text { in months }\end{array}$ & $\begin{array}{l}\text { Average ageing period classification } \\
\text { accuracy per ageing period }(\%)\end{array}$ & $\begin{array}{c}\text { Average ageing period } \\
\text { classification accuracy }(\%)\end{array}$ \\
\hline \multirow{5}{*}{1} & \multirow{5}{*}{$\mathrm{R} 1$} & 1 & 83.07 & \multirow{5}{*}{82.2} \\
\hline & & 3 & 80.27 & \\
\hline & & 6 & 81.6 & \\
\hline & & 9 & 82.2 & \\
\hline & & 12 & 83.87 & \\
\hline \multirow{5}{*}{2} & \multirow{5}{*}{$\mathrm{R} 2$} & 1 & 93.6 & \multirow{5}{*}{93.07} \\
\hline & & 3 & 92.4 & \\
\hline & & 6 & 91.87 & \\
\hline & & 9 & 93.33 & \\
\hline & & 12 & 94.13 & \\
\hline \multirow{5}{*}{3} & \multirow{5}{*}{$\mathrm{R} 3$} & 1 & 82.07 & \multirow{5}{*}{81.49} \\
\hline & & 3 & 80.6 & \\
\hline & & 6 & 80.33 & \\
\hline & & 9 & 85.6 & \\
\hline & & 12 & 78.87 & \\
\hline
\end{tabular}

Table 7. Color features in reduced feature set $\mathbf{R 2}$.

\begin{tabular}{|c|l|c|c|l|c|}
\hline Sl. No & Color feature & $\begin{array}{c}\text { Feature } \\
\text { identifier }\end{array}$ & Sl. No & Color feature & $\begin{array}{c}\text { Feature } \\
\text { identifier }\end{array}$ \\
\hline 1 & Red Mean & F1 & 6 & Blue Standard Deviation & F10 \\
\hline 2 & Red Standard Deviation & F2 & 7 & Hue Mean & F13 \\
\hline 3 & Green Mean & F5 & 8 & Hue Standard Deviation & F14 \\
\hline 4 & Green Standard Deviation & F6 & 9 & Intensity Mean & F21 \\
\hline 5 & Blue Mean & F9 & 10 & Intensity Standard Deviation & F22 \\
\hline
\end{tabular}

Table 8. Ageing period classification results of all the paddy varieties using reduced ten color features from set R2 (Performance Threshold $\rightarrow$ 30\%).

\begin{tabular}{|c|l|c|c|c|c|c|}
\hline \multirow{2}{*}{ SI. No } & \multirow{2}{*}{ Paddy variety } & \multicolumn{3}{|c|}{ Classification accuracy per ageing period (\%) } \\
\cline { 3 - 7 } & & $\begin{array}{c}\mathbf{1} \\
\text { Month }\end{array}$ & $\begin{array}{c}\mathbf{3} \\
\text { Months }\end{array}$ & $\begin{array}{c}\mathbf{6} \\
\text { Months }\end{array}$ & $\begin{array}{c}\mathbf{9} \\
\text { Months }\end{array}$ & $\begin{array}{c}\mathbf{1 2} \\
\text { Months }\end{array}$ \\
\hline 1 & Abhilasha & 92 & 92 & 94 & 94 & 96 \\
\hline 2 & Bhagyajyothi & 94 & 96 & 90 & 96 & 94 \\
\hline 3 & Budda & 96 & 90 & 86 & 94 & 92 \\
\hline 4 & Intan & 90 & 92 & 90 & 94 & 94 \\
\hline 5 & Jaya & 94 & 90 & 92 & 88 & 98 \\
\hline 6 & Jayashree & 90 & 92 & 90 & 94 & 90 \\
\hline 7 & Mugad Dodiga & 96 & 92 & 96 & 94 & 94 \\
\hline 8 & Mugad Sughand & 94 & 94 & 92 & 92 & 96 \\
\hline
\end{tabular}




\begin{tabular}{|l|l|l|l|l|l|l|}
9 & Mugad 101 & 94 & 96 & 90 & 94 & 96 \\
\hline 10 & Mugad Siri & 94 & 90 & 94 & 92 & 98 \\
\hline 11 & PSB 68 & 96 & 90 & 96 & 94 & 94 \\
\hline 12 & Rajkaima & 92 & 94 & 88 & 92 & 86 \\
\hline 13 & Redjyothi & 96 & 92 & 92 & 94 & 96 \\
\hline 14 & Thousand Ten & 92 & 92 & 94 & 94 & 92 \\
\hline 15 & Thousand One & 94 & 94 & 94 & 94 & 96 \\
\hline $\begin{array}{c}\text { Average Ageing Period Classification Accuracy per } \\
\text { ageing period (\%) }\end{array}$ & 93.60 & 92.40 & 91.87 & 93.33 & 94.13 \\
\hline
\end{tabular}

Table 9. The confusion matrix for the classification of ageing periods using ten reduced color features.

\begin{tabular}{|c|c|c|c|c|c|c|c|c|}
\hline \multirow{2}{*}{$\begin{array}{l}\text { Sl. } \\
\text { No }\end{array}$} & \multirow{2}{*}{ Paddy variety } & \multirow{2}{*}{$\begin{array}{c}\text { Actual ageing } \\
\text { periods in } \\
\text { months }\end{array}$} & \multicolumn{5}{|c|}{ Predicted ageing periods in months } & \multirow{2}{*}{$\begin{array}{l}\text { Total number of } \\
\text { test images per } \\
\text { ageing period }\end{array}$} \\
\hline & & & 1 & 3 & 6 & 9 & 12 & \\
\hline \multirow{5}{*}{1} & \multirow{5}{*}{ Abhilasha } & 1 & 46 & 3 & 1 & 0 & 0 & 50 \\
\hline & & 3 & 2 & 46 & 2 & 0 & 0 & 50 \\
\hline & & 6 & 0 & 1 & 48 & 1 & 0 & 50 \\
\hline & & 9 & 0 & 0 & 0 & 48 & 2 & 50 \\
\hline & & 12 & 0 & 1 & 0 & 1 & 48 & 50 \\
\hline \multirow{5}{*}{2} & \multirow{5}{*}{ Bhagyajyothi } & 1 & 47 & 2 & 1 & 0 & 0 & 50 \\
\hline & & 3 & 0 & 48 & 1 & 1 & 0 & 50 \\
\hline & & 6 & 1 & 2 & 45 & 2 & 0 & 50 \\
\hline & & 9 & 0 & 0 & 1 & 47 & 2 & 50 \\
\hline & & 12 & 0 & 1 & 2 & 1 & 46 & 50 \\
\hline \multirow{5}{*}{3} & \multirow{5}{*}{ Budda } & 1 & 48 & 2 & 0 & 0 & 0 & 50 \\
\hline & & 3 & 1 & 45 & 3 & 1 & 0 & 50 \\
\hline & & 6 & 1 & 2 & 43 & 3 & 1 & 50 \\
\hline & & 9 & 0 & 0 & 1 & 47 & 2 & 50 \\
\hline & & 12 & 0 & 1 & 1 & 2 & 46 & 50 \\
\hline \multirow{5}{*}{4} & \multirow{5}{*}{ Intan } & 1 & 47 & 2 & 1 & 0 & 0 & 50 \\
\hline & & 3 & 0 & 48 & 1 & 1 & 0 & 50 \\
\hline & & 6 & 1 & 2 & 45 & 2 & 0 & 50 \\
\hline & & 9 & 0 & 0 & 1 & 47 & 2 & 50 \\
\hline & & 12 & 0 & 1 & 2 & 1 & 46 & 50 \\
\hline \multirow{5}{*}{5} & \multirow{5}{*}{ Jaya } & 1 & 47 & 1 & 1 & 1 & 0 & 50 \\
\hline & & 3 & 3 & 45 & 1 & 1 & 0 & 50 \\
\hline & & 6 & 1 & 1 & 46 & 2 & 0 & 50 \\
\hline & & 9 & 0 & 0 & 3 & 44 & 3 & 50 \\
\hline & & 12 & 0 & 0 & 0 & 1 & 49 & 50 \\
\hline \multirow{5}{*}{6} & \multirow{5}{*}{ Jayashree } & 1 & 45 & 2 & 2 & 1 & 0 & 50 \\
\hline & & 3 & 2 & 46 & 1 & 1 & 0 & 50 \\
\hline & & 6 & 1 & 2 & 45 & 2 & 0 & 50 \\
\hline & & 9 & 0 & 0 & 1 & 47 & 2 & 50 \\
\hline & & 12 & 0 & 1 & 2 & 2 & 45 & 50 \\
\hline \multirow{5}{*}{7} & \multirow{5}{*}{ Mugad Dodiga } & 1 & 48 & 2 & 0 & 0 & 0 & 50 \\
\hline & & 3 & 2 & 46 & 1 & 1 & 0 & 50 \\
\hline & & 6 & 0 & 1 & 48 & 1 & 0 & 50 \\
\hline & & 9 & 0 & 0 & 1 & 47 & 2 & 50 \\
\hline & & 12 & 0 & 0 & 2 & 1 & 47 & 50 \\
\hline
\end{tabular}


Table 9. Confusion matrix for the classification of ageing periods using ten reduced color features (Continued...).

\begin{tabular}{|c|c|c|c|c|c|c|c|c|}
\hline \multirow{2}{*}{ SI. No } & \multirow{2}{*}{ Paddy variety } & \multirow{2}{*}{$\begin{array}{l}\text { Actual ageing } \\
\text { periods in } \\
\text { months }\end{array}$} & \multicolumn{5}{|c|}{ Predicted ageing periods in months } & \multirow{2}{*}{$\begin{array}{c}\text { Total number } \\
\text { of test images } \\
\text { per ageing } \\
\text { period }\end{array}$} \\
\hline & & & 1 & 3 & 6 & 9 & 12 & \\
\hline \multirow{5}{*}{8} & \multirow{5}{*}{ Mugad Sughand } & 1 & 47 & 3 & 0 & 0 & 0 & 50 \\
\hline & & 3 & 2 & 47 & 1 & 0 & 0 & 50 \\
\hline & & 6 & 1 & 2 & 46 & 1 & 0 & 50 \\
\hline & & 9 & 0 & 0 & 2 & 46 & 2 & 50 \\
\hline & & 12 & 0 & 0 & 1 & 1 & 48 & 50 \\
\hline \multirow{5}{*}{9} & \multirow{5}{*}{ Mugad 101} & 1 & 47 & 2 & 1 & 0 & 0 & 50 \\
\hline & & 3 & 0 & 48 & 1 & 1 & 0 & 50 \\
\hline & & 6 & 1 & 2 & 45 & 2 & 0 & 50 \\
\hline & & 9 & 0 & 0 & 1 & 47 & 2 & 50 \\
\hline & & 12 & 0 & 1 & 2 & 1 & 46 & 50 \\
\hline \multirow{5}{*}{10} & \multirow{5}{*}{ Mugad Siri } & 1 & 47 & 2 & 1 & 0 & 0 & 50 \\
\hline & & 3 & 3 & 45 & 2 & 0 & 0 & 50 \\
\hline & & 6 & 0 & 2 & 47 & 1 & 0 & 50 \\
\hline & & 9 & 0 & 0 & 2 & 46 & 2 & 50 \\
\hline & & 12 & 0 & 0 & 0 & 1 & 49 & 50 \\
\hline \multirow{5}{*}{11} & \multirow{5}{*}{ PSB 68} & 1 & 48 & 1 & 1 & 0 & 0 & 50 \\
\hline & & 3 & 1 & 45 & 2 & 2 & 0 & 50 \\
\hline & & 6 & 0 & 2 & 48 & 0 & 0 & 50 \\
\hline & & 9 & 0 & 0 & 2 & 47 & 1 & 50 \\
\hline & & 12 & 0 & 0 & 2 & 1 & 47 & 50 \\
\hline \multirow{5}{*}{12} & \multirow{5}{*}{ Rajkaima } & 1 & 46 & 2 & 2 & 0 & 0 & 50 \\
\hline & & 3 & 0 & 47 & 2 & 1 & 0 & 50 \\
\hline & & 6 & 1 & 3 & 44 & 2 & 0 & 50 \\
\hline & & 9 & 0 & 0 & 2 & 46 & 2 & 50 \\
\hline & & 12 & 0 & 0 & 4 & 3 & 43 & 50 \\
\hline \multirow{5}{*}{13} & \multirow{5}{*}{ Redjyothi } & 1 & 48 & 2 & 0 & 0 & 0 & 50 \\
\hline & & 3 & 0 & 46 & 3 & 1 & 0 & 50 \\
\hline & & 6 & 0 & 3 & 46 & 1 & 0 & 50 \\
\hline & & 9 & 0 & 0 & 2 & 47 & 1 & 50 \\
\hline & & 12 & 0 & 0 & 1 & 1 & 48 & 50 \\
\hline \multirow{5}{*}{14} & \multirow{5}{*}{ Thousand Ten } & 1 & 46 & 2 & 1 & 0 & 0 & 49 \\
\hline & & 3 & 2 & 46 & 1 & 1 & 0 & 50 \\
\hline & & 6 & 0 & 2 & 47 & 1 & 0 & 50 \\
\hline & & 9 & 0 & 0 & 1 & 47 & 2 & 50 \\
\hline & & 12 & 0 & 0 & 1 & 1 & 48 & 50 \\
\hline \multirow{5}{*}{15} & \multirow{5}{*}{ Thousand One } & 1 & 47 & 3 & 0 & 0 & 0 & 50 \\
\hline & & 3 & 0 & 47 & 2 & 1 & 0 & 50 \\
\hline & & 6 & 0 & 2 & 47 & 1 & 0 & 50 \\
\hline & & 9 & 0 & 0 & 3 & 47 & 0 & 50 \\
\hline & & 12 & 0 & 0 & 1 & 1 & 48 & 50 \\
\hline
\end{tabular}

Table 10. Comparison of proposed work with the reported work.

\begin{tabular}{|c|c|c|c|c|c|c|c|c|}
\hline Author & $\begin{array}{c}\text { Number of } \\
\text { varieties } \\
\text { considered }\end{array}$ & $\begin{array}{c}\text { Ageing } \\
\text { periods }\end{array}$ & $\begin{array}{c}\text { Data } \\
\text { set size }\end{array}$ & Features & $\begin{array}{c}\text { Feature } \\
\text { reduction } \\
\text { method }\end{array}$ & $\begin{array}{c}\text { Reduced } \\
\text { feature } \\
\text { set size }\end{array}$ & $\begin{array}{c}\text { Mean } \\
\text { Classifier } \\
\text { classification } \\
\text { accuracy }\end{array}$ \\
\hline $\begin{array}{c}\text { Xiaoli Li } \\
\text { et. al. } \\
(2008)\end{array}$ & 4 & $\begin{array}{c}1,2,3 \\
\text { and } 4 \\
\text { years }\end{array}$ & $\begin{array}{c}210 \\
\text { images }\end{array}$ & $\begin{array}{c}\text { Wavelet } \\
\text { features }\end{array}$ & $\begin{array}{c}\text { Principal } \\
\text { Component } \\
\text { Analysis }\end{array}$ & 8 & $\begin{array}{c}\text { ANN with } \\
\text { Backpropagation }\end{array}$ & 97.5 \\
\hline $\begin{array}{c}\text { Proposed } \\
\text { Work }\end{array}$ & 15 & $\begin{array}{c}1,3,6,9 \\
\text { and } 12 \\
\text { months }\end{array}$ & $\begin{array}{c}7500 \\
\text { images }\end{array}$ & $\begin{array}{c}\text { Color } \\
\text { features }\end{array}$ & $\begin{array}{c}\text { Performance } \\
\text { based feature } \\
\text { reduction }\end{array}$ & 10 & $\begin{array}{c}\text { ANN with } \\
\text { Backpropagation }\end{array}$ & 93.07 \\
\hline
\end{tabular}

